\title{
DEGRADATION DYNAMICS AND PROCESSES ASSOCIATED WITH THE ACCUMULATION OF LAMINARIA HYPERBOREA (PHAEOPHYCEAE) KELP FRAGMENTS: AN IN SITU EXPERIMENTAL APPROACH ${ }^{1}$
}

\author{
Florian de Bettignies (iD) ${ }^{2}$ \\ Sorbonne Université, CNRS, UMR 7144 AD2M, Station Biologique de Roscoff, Place Georges Teissier, Roscoff F-29680, France \\ Patrick Dauby \\ FOCUS unit, Systematics and Animal Diversity, University of Liège, Sart Tilman B6c, B-4000 Liège, Belgium

\section{Francois Thomas (iD, Angélique Gobet (iD, Ludovic Delage} \\ Integrative Biology of Marine Models (LBI2M), Station Biologique de Roscoff (SBR), Sorbonne Université, CNRS, Roscoff 29680, \\ France \\ Olivier Bohner, Stéphane Loisel, and Dominique Davoult (D) \\ Sorbonne Université, CNRS, UMR 7144 AD2M, Station Biologique de Roscoff, Place Georges Teissier, Roscoff F-29680, France
}

A high proportion of the kelp Laminaria hyperborea production is exported from kelp forests following seasonal storms or natural annual old blade loss. Transport of drifting kelp fragments can lead to temporary accumulations in benthic subtidal habitats. We investigated the degradation processes of $L$. hyperborea in a low subtidal sandy bottom ecosystem by setting up a 6-month cage experiment to simulate accumulations of kelp fragments on the seafloor. We monitored temporal changes in biomass, nutritional quality (C:N ratio), respiration, quantum efficiency of photosystem II $\left(F_{\mathrm{v}} / F_{\mathrm{m}}\right)$, bacterial colonization, and chemical defense concentrations. Biomass decomposition started after 2 weeks and followed a classic negative exponential pattern, leading to $50 \%$ degradation after 8 weeks. The degradation process seemed to reach a critical step after 11 weeks, with an increase in respiration rate and phlorotannin concentration in the tissues. These results likely reflect an increase in bacterial activity and a weakening of the kelp cell wall. After 25 weeks of degradation, only $16 \%$ of the initial biomass persisted, but the remaining large fragments looked intact. Furthermore, photosystems were still responding to light stimuli, indicating that photosynthesis persisted over time. Reproductive tissues appeared on some fragments after 20 weeks of degradation, showing a capacity to maintain the reproductive function. Our results indicate that $L$. hyperborea fragments degrade slowly. As they maintain major physiological functions (photosynthesis, reproduction, etc.) and accumulate on adjacent ecosystems, they may play a long-term ecological role in coastal ecosystem dynamics.

\footnotetext{
${ }^{1}$ Received 31 July 2019. Accepted 27 May 2020.

${ }^{2}$ Authors for correspondence: e-mail f.debettig-nies@sb-roscoff.fr

Editorial Responsibility: T. Wernberg (Associate Editor)
}

Key index words: bacteria; composition; degradation; detritus; kelp; metabolism; organic matter

Abbreviations: CFU, Colony-forming units; DM, Dry mass; $F_{0}$, Minimum fluorescence; $F_{\mathrm{m}}$, Maximum fluorescence; $F_{\mathrm{v}}$, Variable fluorescence; $F_{\mathrm{v}} / F_{\mathrm{m}}$, Maximum quantum yield of photosystem II; $k$, Decomposition rate; RM, Remaining biomass; RWM, Relative water motion; $T_{1 / 2}$, Half-life of fragment detritus; WM, Wet mass

Degradation is a key process in the organic matter cycle and drives biogenic ecosystems in terrestrial and marine environments. Degradation includes the decomposition (biomass breakdown) of primary producers and litter, and leads to remineralization driven by micro- and macro-organisms that colonize the organic matter (Rees et al. 2001, Pandey et al. 2007, Polyakova and Billor 2007). Litterfall amounts and dynamics are closely linked to the growth and productivity of source ecosystems (Miller 1984, Matala et al. 2008). In terrestrial ecosystems, plant decomposition rates vary with lignin, nitrogen content (Hendricks and Boring 1992, Wesemael and Veer 1992), and environmental conditions, such as litterfall moisture or temperature (Krishna and Mohan 2017). In contrast to terrestrial environments, seawater flow creates much higher and more complex lateral transport of detritus, and thus lower accumulation of litter below the canopy. Despite these major differences, accumulations of seagrasses (Pergent et al. 1994, Cardona et al. 2007) and macroalgae are observed on the seafloor from deep (Vetter 1994, Filbee-Dexter and Scheibling 2014) to subtidal (Tzetlin et al. 1997) and intertidal habitats (Bustamante et al. 1995). 
Among macroalgae, kelps are major components of marine ecosystem functioning in temperate and sub-polar regions around the globe. Kelp forests play a key role in coastal environments as habitatforming species, wave-energy dissipaters, and major actors in the carbon cycle (Christie et al. 2003, Leclerc et al. 2015, Teagle et al. 2017). Kelps are fast-growing primary producers that accumulate a large quantity of organic matter via photosynthesis $\left(>1 \mathrm{~kg} \mathrm{C} \cdot \mathrm{m}^{-2} \cdot\right.$ year $^{-1}$; Mann 1973). A high proportion of the annual kelp production is exported (about $82 \%$ in Krumhansl and Scheibling 2012a), due to blade erosion, natural mortality, or dislodgment related to strong hydrodynamic events (Krumhansl and Scheibling 2012a, de Bettignies et al. 2013, Pessarrodona et al. 2018). Detrital material can drift across habitats and accumulate in benthic ecosystems when hydrodynamic conditions are suitable, strongly influencing the recipient trophic food web (Tzetlin et al. 1997, Krumhansl and Scheibling 2012b, Vilas et al. 2020). Settled kelp detritus plays a primary source role by attracting numerous species and enhancing secondary production (reviewed in Krumhansl and Scheibling 2012a). Kelp detritus can also subsidize local primary producers by providing nutrients during degradation (Hyndes et al. 2012). The residence time of deposits strongly influences the composition and the dynamics of macrofaunal-associated community (Norkko et al. 2000, Okey 2003) as well as the burial rate of kelp organic matter within underlying sediment (Abdullah et al. 2017).

Laminaria hyperborea (Laminariales) is a dominant kelp species in the North-East Atlantic, distributed from Portugal to Norway (Steneck et al. 2002). In Brittany, France, this species dominates subtidal rocky ecosystems from 0 to $30 \mathrm{~m}$ depth. Growth of L. hyperborea sporophytes occurs in winter and spring, ceasing in July (Lüning 1979). In spring, $L$. hyperborea retains the old blade from the previous year during the rapid growth of the new blade. Between April and May, the old blade is shed from the fast-growing new blade (May cast). The release of the previous season's blade contributes significantly to the total detritus production (Pessarrodona et al. 2018). Prior to the May cast, dislodgment of part of plants during winter and spring storms can export both old and new blade detritus across adjacent ecosystems (Pessarrodona et al. 2018). Old and new blades have different tissue content (Sjøtun et al. 1996, Schiener et al. 2015), texture, or toughness (Toth and Pavia 2002). Their degradation rate should thus be distinct.

Laminaria hyperborea detritus represents a trophic resource that connects habitats (Filbee-Dexter et al. 2018), becoming increasingly accessible to consumers during degradation (Norderhaug et al. 2003). In some kelp forests, grazers only consume a small fraction of kelp productivity (Hereward et al. 2018), whereas in other regions, grazing by sea urchins is a major structuring process (Ling et al. 2014). In Norway, some L. hyperborea populations have been subject to overgrazing by the green sea urchin Strongylocentrotus droebachiensis and the edible sea urchin Echinus esculentus (Sivertsen 1997). In Brittany, below the southern distribution of $S$. droebachiensis, only a few grazers including E. esculentus are able to feed on kelps, but a local study based on stable isotopes has indicated that E. esculentus has a mixed diet largely dominated by sessile fauna (Leclerc et al. 2015). Hence, grazers locally consume a small fraction of the $L$. hyperborea production, while a high proportion is exported to adjacent ecosystems. Therefore, understanding the kinetics of L. hyperborea detritus biomass decomposition is essential.

Here, we examined Laminaria hyperborea decomposition dynamics and the degradation processes in situ. We used litterfall cages to simulate drift kelp accumulation on a sandy bottom ecosystem for 6 months. We compared the biomass decomposition kinetics of new versus old blades to assess potential differences in their degradation rate and residence time. Focusing on new blades, we further investigated the degradation processes leading to biomass decomposition. We measured in situ respiration rates to assess changes in community metabolism and bacterial activity. In addition, we quantified the abundance of cultivable associated bacteria. We measured the concentration of phlorotannins within kelp tissue, often related to defense mechanisms (reviewed in Amsler and Fairhead 2006), and the content in carbon (C) and nitrogen (N), often related to nutritional quality and palatability (Norderhaug et al. 2006). We tested if degradation leads to a decline in phlorotannin concentration and an enrichment in $\mathrm{N}$ and thus increases the availability of fragments for micro- and macro-organisms. Finally, we investigated the maintenance of photosynthesis and reproduction to test if L. hyperborea detritus continues to fulfill primary producer functions when fragmented and exported as observed in some floating kelp species (e.g., Macaya et al. 2005, Tala et al. 2013).

This set of measures was performed to test the main following hypotheses: (1) the respiration of kelp detritus will first decrease together with a decrease in kelp metabolism and then increase together with an increase in bacterial activity, (2) the kelp defense (phlorotannins) will first increase in response to stress and micro- and macro-organism colonization then will decrease as a consequence of tissue degradation and (3) the photosynthetic activity will decline after a few weeks of degradation.

\section{MATERIALS AND METHODS}

Study site. The present study was conducted near Roscoff, in the Bay of Morlaix, along the north-western coast of 
Brittany, France. The bay is composed of numerous rocky reefs supporting high Laminaria hyperborea biomass stock (Gorman et al. 2013), separated by large areas of fine and soft sediments that temporarily receive accumulations of drift kelp (F. de Bettignies, pers. obs.). Diving surveys carried out in the bay have revealed areas of kelp accumulations that can last several months, in shallow sandy bottoms adjacent to rocky reefs (10 $\mathrm{m}$ average depth) as well as in channels at the base of rocky drop-offs ( $30 \mathrm{~m}$ average depth). The experimental site (Guerhéon: 48 42'33.78” N, 0357'12.36” W) was located in a semi-enclosed part of the bay, protected from the prevailing westerly winds, but exposed to north and easterly winds that occasionally occur during spring and summer anticyclonic conditions. The site substratum was characterized by a mixture of coarse sand and shell fragments at $4.5 \mathrm{~m}$ depth below chart datum (9 $\mathrm{m}$ average depth) and distant by ca. $100 \mathrm{~m}$ from rocky reefs covered with kelp forests.

Experimental design. We set up an in situ cage experiment to investigate the degradation dynamics of Laminaria hyperborea on a subtidal sandy ecosystem (Fig. 1). The study was conducted from April, $18^{\text {th }}$ to October, $5^{\text {th }} 2017$ (5.5 months). The experiment was started in April to mimic spring storm events that dislodge both the old blade and the recently grown new blade.

Whole adults of Laminaria hyperborea were randomly collected via scuba diving from a natural population on a rocky reef close to the experimental site. We selected individuals with an $80-90 \mathrm{~cm}$ stipe length, corresponding to average adults composing the canopy, without visible signs of degradation. Kelp samples were kept in seawater and brought back to the harbor where they were processed within 2 hours. New blades were cut once along their length and their width to obtain fragments of various sizes, similar to those found in the field. Fragments from two individuals were pooled and weighed with a digital spring scale (Amiaud Durer, $40 \mathrm{~kg}$ $\pm 10 \mathrm{~g}$ ) for a mean $\pm \mathrm{SD}$ wet mass of $911 \pm 105 \mathrm{~g}$. Batches were gently packed and randomly allocated to custom-built numbered plastic litterfall cages $(30 \times 25 \times 10 \mathrm{~cm}, 1 \mathrm{~cm}$ mesh) made of high-density polyethylene mesh used in oyster farming. The quantity of algal material in the cage mimicked a 10-cm thick accumulation of kelp fragments with a three-dimensional structure, as previously observed during survey dives. A total of 35 litterfall cages were prepared with new blades, kept in seawater and quickly immersed at the experimental site by divers. To compare the degradation kinetics between new and old blades, five litterfall cages were filled with old blade fragments following the same procedure. Cages were attached on four anchored chain lines arranged parallel to each other, forming a relatively continuous rectangle of accumulated fragments (Fig. 1). We checked the cages throughout the experiment to ensure that they were not buried in sediment. At each sampling time $(2,4,6,11,15,20$, 24 weeks), five replicates of new-blade litterfall cages were randomly collected. Additionally, one old-blade litterfall cage was randomly collected at five sampling dates $(4,6,11,15$, 20 weeks) for degradation rate measurement. Collection was carried out by carefully enclosing each cage within a 1-mm mesh bag. At each sampling time, 3 new-blade litterfall cages, among the 5 collected, were randomly selected for in situ incubation to measure respiration. All the cages were then brought to the surface and transported within site seawater to the aquarium facilities. Tissue sampling for bacterial counts was conducted immediately after their arrival to avoid any contamination. Cages were then kept in the dark in a continuous-flow seawater tank with constant air bubbling until further laboratory measurements (performed within $24 \mathrm{~h}$ ).

Field measurements. Environmental parameters: An array of environmental sensors was deployed on the experimental site to measure temperature, light intensity, and water motion over the six-month period. Temperature and light intensity were measured with the same sensor (HOBO Pendant Temperature/Light Weatherproof Pendant Data Logger 16K) attached to a plate fixed horizontally on a threaded rod at $20 \mathrm{~cm}$ from a concrete block. Relative water motion (RWM) was measured with an accelerometer (HOBO Pendant G Data Logger) attached to a small dome-shaped buoy. The buoy was tethered to the seabed with a $0.75 \mathrm{~m}$ rope clamp on a different concrete block, as previously described (Bennett et al. 2015). These sensors were deployed $3 \mathrm{~m}$ from the experimental system, with a replicate set to offset any sensor failure. At each sampling time, sensors were changed or cleaned to prevent excessive fouling on the rope or on the sensor. All sensors were programmed to take one measurement every five minutes. For the RWM, two channels were used $(x, y)$ to account for horizontal acceleration (cf. $\mathrm{H}_{2} \mathrm{O}$ motion V2 design; Evans and Abdo 2010). The sensor was set to record acceleration $\left(\mathrm{m} \cdot \mathrm{s}^{-2}\right)$. The RWM was standardized and measured as the vector sum for all pairwise recordings as previously described (Evans and Abdo 2010). For each sampling time, the maximum, minimum, and average values of the previous week were measured for temperature and RWM. Only the daily average of the previous week was measured for light.

In situ litterfall cage respiration rate: Litterfall cage respiration rates were measured at the experimental site during each collection time on three of the five randomly collected new-blade litterfall cages. Custom-built benthic incubation chambers were set up in situ by scuba divers. They consisted of a base to isolate the cage from the sediment, a Plexiglas cylinder, a dome sealed by a clamp system enclosing a total volume of $26.2 \mathrm{~L}$ of seawater and an autonomous stirrer to ensure continuous mixing (Ouisse et al. 2014). Care was taken to avoid trapping of air bubbles during chamber assembly. Each of the three selected cages enclosed in a mesh bag was allocated to a separate benthic chamber and covered by black tarpaulins to ensure darkness. Seawater samples were collected from each chamber at the beginning and at the end of the $30 \mathrm{~min}$ incubation period (two-point method) by using $100 \mathrm{~mL}$ syringes and directly brought to the surface. Dissolved oxygen concentration was immediately measured on the boat using a portable multi-meter (HQ40d, Hach ${ }^{\circledR}$, Loveland, CO, USA) coupled with a luminescent/optical dissolved oxygen probe $\left(\right.$ Intellical ${ }^{\mathrm{TM}}$ LDO101, Hach ${ }^{\circledR}$, accuracy $\left.\pm 0.2 \mathrm{mg} \cdot \mathrm{L}^{-1}\right)$. Litterfall cage respiration rate was estimated from the difference between initial and final oxygen $\left(\mathrm{O}_{2}\right)$ concentrations after correction for temperature change. Respiration was expressed as $\mathrm{O}_{2}$ consumption in $\mathrm{mgO}_{2} \cdot \mathrm{kg} \mathrm{WM} \mathrm{WM}^{-1} \cdot \mathrm{h}^{-1}$, to allow comparisons over time. Although continuous $\mathrm{O}_{2}$ measurement is recommended, measurements only at the beginning and at the end of the incubation are considered acceptable to obtain a correct measurement of community metabolism for short incubations (Ouisse et al. 2014).

Laboratory measurements. Cultivable bacteria counts: For each new-blade litterfall cage, 10 pieces of algal tissue were collected using a stainless steel punch (13 mm diameter) sterilized by flaming with $70 \%$ ethanol. Algal pieces were transferred to $20 \mathrm{~mL}$ of sterile saline solution (for $1 \mathrm{~L}: 24.7 \mathrm{~g}$ $\left.\mathrm{NaCl}, 6.3 \mathrm{~g} \quad \mathrm{MgSO}_{4} \cdot 7 \mathrm{H}_{2} \mathrm{O}, 4.6 \mathrm{~g} \quad \mathrm{MgCl}_{2} \cdot \mathrm{H}_{2} \mathrm{O}, 0.7 \mathrm{~g} \mathrm{KCl}\right)$, stored on ice and returned within $1 \mathrm{~h}$ to the laboratory for further processing. The 10 algal pieces from one cage were rinsed twice in a $20 \mathrm{~mL}$ sterile saline solution and homogenized in a single batch for $1 \mathrm{~min}$ at $8000 \mathrm{rpm}$ in a $20 \mathrm{~mL}$ sterile saline solution using a T25 Ultra-Turrax blender, followed by $1 \mathrm{~min}$ of vortex agitation at maximum speed. Serial dilutions (from $10^{-1}$ to $10^{-4}$ ) of homogenates were prepared in sterile saline solution. Then, $100 \mu \mathrm{L}$ of the dilutions was spread-plated in duplicate and incubated at $20^{\circ} \mathrm{C}$ for $7 \mathrm{~d}$. 


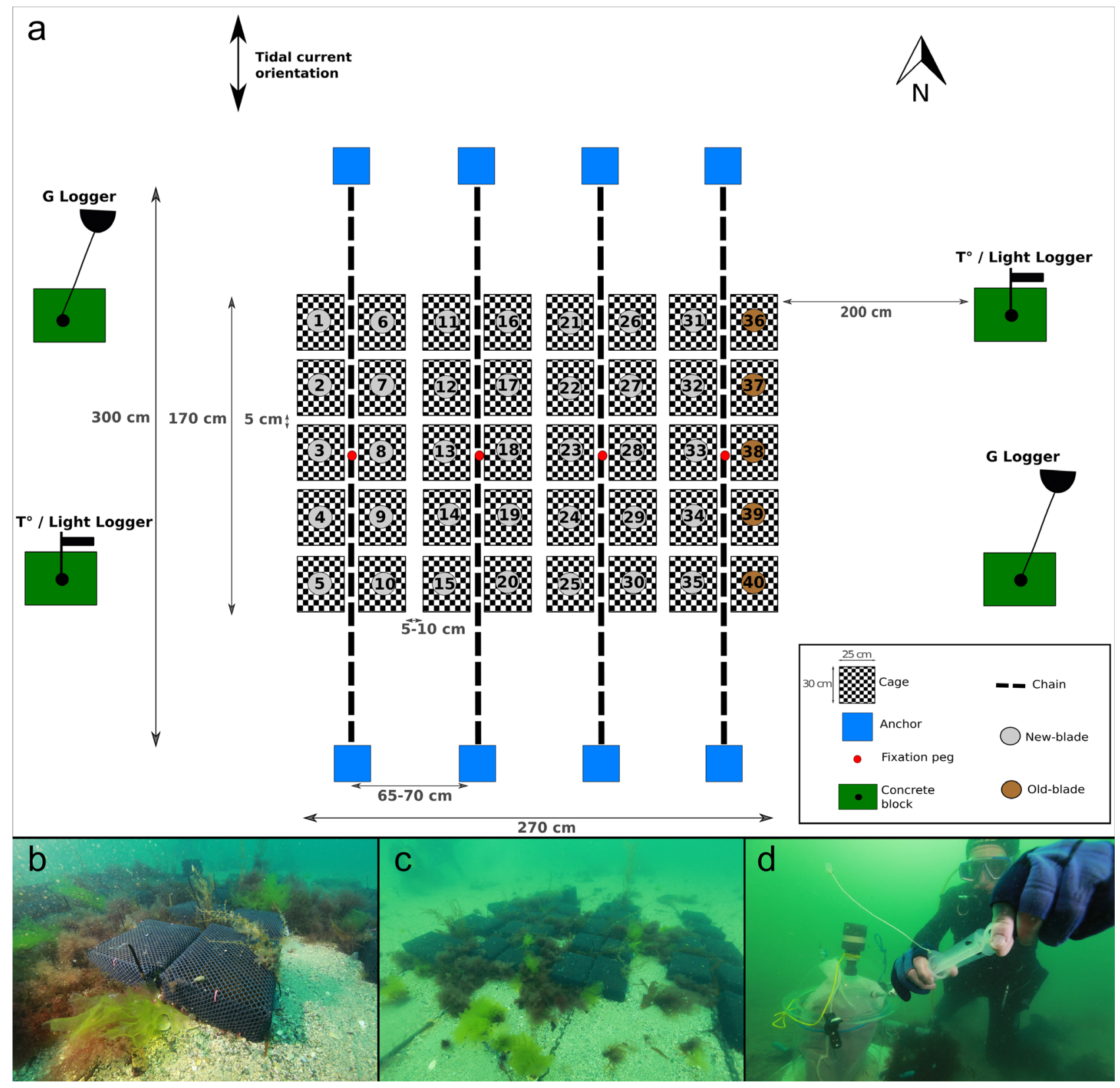

Fig. 1. (a) In situ experimental set-up on the seabed in the Bay of Morlaix (Guerhéon: 4842’33.78” N, 0357’12.36” W) at 9 m depth (on average). Panel (b) shows 40 custom-built plastic cages filled with $1 \mathrm{~kg}$ of fresh Laminaria hyperborea blades arranged to form an artificial accumulation of kelp fragments (c). (d) Benthic chamber incubations to estimate the holobiont respiration rates. Photographs: Wilfried Thomas, experimental schematic: Florian de Bettignies.

Four media were used to screen cultivable bacteria presenting different functions. The Zobell agar medium (for $1 \mathrm{~L}: 5 \mathrm{~g}$ tryptone, $1 \mathrm{~g}$ yeast extract, $15 \mathrm{~g}$ agar in natural seawater), a highly nutritive medium, was used as a proxy of the total community of cultivable bacteria. Bacteria resisting high concentrations of iodine, one of the defense compounds released by kelps (Verhaeghe et al. 2008), were screened on a Zobell agar medium supplemented with $100 \mathrm{mM}$ KI. Bacteria were also grown on a minimum medium solidified with Phytagel (for $1 \mathrm{~L}$ : $24.7 \mathrm{~g} \mathrm{NaCl}, 6.3 \mathrm{~g} \mathrm{MgSO}_{4} \cdot 7 \mathrm{H}_{2} \mathrm{O}, 4.6 \mathrm{~g}$ $\mathrm{MgCl}_{2} \cdot \mathrm{H}_{2} \mathrm{O}, 2 \mathrm{~g} \quad \mathrm{NH}_{4} \mathrm{Cl}, 0.7 \mathrm{~g} \mathrm{KCl}, 0.6 \mathrm{~g} \mathrm{CaCl}_{2}, 200 \mathrm{mg}$ $\mathrm{NaHCO}_{3}, 100 \mathrm{mg} \mathrm{K} \mathrm{HPO}_{4}$, 1X vitamin mix, $20 \mathrm{mg} \mathrm{FeSO} \cdot \cdot 7$ $\mathrm{H}_{2} \mathrm{O}, 20 \mathrm{~g}$ Phytagel; Thomas et al. 2011) and supplemented with $4 \mathrm{~g} \cdot \mathrm{L}^{-1}$ alginate, a polysaccharide accounting for 10 $45 \%$ of the dry mass of brown algal cell wall (Kloareg and Quatrano 1988) or $4 \mathrm{~g} \cdot \mathrm{L}^{-1}$ mannitol, one of the main carbon storage forms in brown algae (Iwamoto and Shiraiwa 2005). Technical duplicate measurements were averaged and results were expressed as the number of colony-forming units per unit area of algal tissue $\left(\mathrm{cfu} \cdot \mathrm{cm}^{-2}\right)$. The detection limit was $75 \mathrm{cfu} \cdot \mathrm{cm}^{-2}$. The proportion of iodine-resistant cultivable bacteria was estimated as the ratio of counts obtained on KI-supplemented Zobell agar compared to counts obtained on Zobell agar.

Reproductive tissues: Before any other measurements, fragment surfaces were visually checked to describe any form of 
degradation (weakness, bleaching) and to record any appearance of reproductive tissue during the degradation process.

Phlorotannin assay: For each new-blade litterfall cage, 10 disks of algal tissue were randomly collected using a stainless steel punch (28 $\mathrm{mm}$ diameter) and stored at $-20^{\circ} \mathrm{C}$ before processing. Phlorotannin extraction was performed using a method adapted from Li et al. (2017) and Koivikko et al. (2007). Frozen samples were stored overnight at $-80^{\circ} \mathrm{C}$ and freeze-dried for $24 \mathrm{~h}$. First, $100 \mathrm{mg}$ of freeze-dried tissue was ground into a fine homogeneous powder under liquid nitrogen with a mortar and pestle and stored at $-20^{\circ} \mathrm{C}$ until analyses. Extraction was performed at $25^{\circ} \mathrm{C}$ for $30 \mathrm{~min}$ with $0.5 \mathrm{~mL}$ of extraction buffer under constant agitation. The extraction buffer consisted of a 30:70 ethanol:water mixture acidified with hydrochloric acid $(\mathrm{pH}=2.6)$ to prevent oxidation. The extract was centrifuged and the supernatant was stored at $-20^{\circ} \mathrm{C}$. Total soluble phlorotannins were quantified using a modified Folin-Ciocalteu method (Van Alstyne et al. 1999, Zhang et al. 2006) by mixing $10 \mu \mathrm{L}$ of sample, $50 \mu \mathrm{L}$ of Folin-Ciocalteu reagent (Sigma) and $40 \mu \mathrm{L}$ of $\mathrm{Na}_{2} \mathrm{CO}_{3} 7.5 \%$ $(\mathrm{m} / \mathrm{v})$ in multiwell plates (Nunc UV-Star 96 wells). Phloroglucinol (Sigma) was used as a standard. Extracts were diluted 2-10 times with extraction buffer for absorbance to be in the range of the standard curve. Plates were incubated in the dark at room temperature for $2 \mathrm{~h}$, before absorbance was measured at $\lambda=750 \mathrm{~nm}$ on a spectrophotometric microplate reader (Safire ${ }^{2}$ Tecan Multi-detection Microplate reader). For each sampling time, the cage was used as biological replicate $(\mathrm{n}=5)$ and each sample was measured in two technical replicates. Technical replicate values were averaged prior to statistical analyses. Each standard solution was run in triplicate. The concentration of soluble phlorotannins within kelp fragments was calculated according to the phloroglucinol standard curve and expressed in phloroglucinol equivalent in $\mathrm{mg} \cdot \mathrm{g}_{\mathrm{DM}}{ }^{-1}$ (where DM is kelp dry mass).

Carbon-nitrogen content: For each new-blade litterfall cage, 10 disks (28 $\mathrm{mm}$ diameter) were randomly cored on kelp fragments and stored at $-20^{\circ} \mathrm{C}$ until preparation and analysis. Algal samples were rinsed with freshwater to remove possible epiphytes, dried at $60^{\circ} \mathrm{C}$ for $48 \mathrm{~h}$ and ground with a mortar and a pestle. Powder samples were put in tin capsules for C:N analyses. Carbon and nitrogen contents were measured using a Flash EA 1112 CHN analyzer (ThermoFinnigan) coupled with a Finnigan Delta Plus mass spectrometer, via a Finnigan Con-Flo III interface. C:N data were expressed as mass ratio.

Chlorophyll fluorescence measurements: All fluorescence measurements were carried out $24 \mathrm{~h}$ after collection between 4:00 pm and 6:00 pm to avoid differences in physiology related to daily cycles (Gevaert et al. 2002, Edwards and Kim 2010). Blades were transported from the seawater tank to the laboratory inside a dark box filled with seawater. Visually, the degradation state varied with blade fragment size. Fragments were therefore separated in two groups according to their surface area: small $\left(\right.$ area $\left.<25 \mathrm{~cm}^{2}\right)$ and large $\left(\right.$ area $>50 \mathrm{~cm}^{2}$ ) fragments. In vivo $\mathrm{Chl}$ a fluorescence of photosystem II (PSII) was measured from the center of three small and three large fragments randomly selected from each of the five new-blade cages collected. Before measurement, fragments were dark-adapted for 15 min using a Dark Leaf Clip Diving-LC (Walz) connected to an underwater pulse amplitude modulated fluorometer (Diving-PAM; Heinz Walz, Effeltrich, Germany). The maximum quantum yield $\left(F_{\mathrm{v}} / F_{\mathrm{m}}\right)$ of PSII, here used as a proxy for physiological capacity, was measured using a $0.8 \mathrm{~s}$ saturating light pulse of white light $\left(2500 \mu \mathrm{mol}\right.$ photons $\left.\cdot \mathrm{m}^{-2} \cdot \mathrm{s}^{-1}\right) \cdot F_{\mathrm{v}}$ represents the variable fluorescence and corresponds to the difference between the minimum fluorescence yield $\left(F_{0}\right)$ measured under weak red modulated light and the maximal fluorescence $\left(F_{\mathrm{m}}\right)$ measured following the short saturating light pulse.

Remaining biomass: The remaining fragments from each litterfall cage were air-dried for $1 \mathrm{~min}$ and wet-weighed (wet mass, WM). Samples were then dried at $60^{\circ} \mathrm{C}$ for at least $48 \mathrm{~h}$ until reaching a constant mass before being reweighed (dry mass, DM). The remaining biomass was estimated by dividing the final WM by the initial WM measured at the beginning of the experiment and expressed in percentage of remaining biomass $(\% \mathrm{RB})$.

A decomposition rate $(k)$ was estimated using a single-pool negative exponential model commonly used in the literature (Olson 1963, Enríquez et al. 1993, Adair et al. 2010). Nonlinear least square regressions were fitted to the mean remaining biomass values (function nls in $\mathrm{R}$ ), according to the following equation:

$$
\% R B_{t}=100 \mathrm{e}^{-k t}
$$

where $\% R B_{t}$ is the remaining biomass at time $t$ in days, 100 represents the initial biomass and $k$ is the decomposition rate of detritus in $\mathrm{d}^{-1}$. From this estimation, the half-life of fragment detritus was measured $\left(T_{1 / 2}=k^{-1} \cdot \operatorname{Ln}(2)\right.$, in d). It gives a more intuitive description of detritus turnover times (Enríquez et al. 1993). Initial data from new and old blade datasets were pooled and fitted with a single decomposition rate model. To test if the fitted values for $k$ differed between the two sets (new vs. old blades), we added an interaction term, allowing $k$ to vary depending on the set. This interaction term was significantly different from zero $(P<0.05)$ indicating that the estimation of $k$ differed significantly from the two sets. The decomposition rate model was thus fitted separately for new and old blade data, with different values of $k$. An F-test was used to test the fit of each model.

Data analysis. Phlorotannin concentrations and C:N contents were compared with a one-way ANOVA using degradation time as fixed factor. Post-hoc comparisons were applied using Tukey's honestly significant difference (HSD) tests when significant ANOVA results were found $(P<0.05)$. Phlorotannin concentration data were transformed by calculating their square-root prior to analysis to meet the assumptions of normality (Shapiro Wilk's test, $\alpha=0.05$ ) and homogeneity of variance (Levene's test, $\alpha=0.05$ ). Remaining biomass, litterfall cage respiration, and bacterial count values were compared using a non-parametric one-way analysis of variance Kruskal-Wallis H-test with degradation time as fixed factor. This procedure was used for biomass data because assumptions of normality and homoscedasticity were not met even after $\log (\mathrm{x})$ and square-root transformations. For litterfall cage respiration and bacterial counts, the low number of replicates $(n=3)$ at each sampling time were not amenable to parametric analyses. Bonferroni adjustment and the low number of replicates precluded the detection of differences by post-hoc Dunn pairwise tests. $F_{\mathrm{v}} / F_{\mathrm{m}}$ data within the same litterfall cage were averaged for small and large fragments prior to analysis, due to data dependency. $F_{\mathrm{v}} / F_{\mathrm{m}}$ values were compared using a two-way nested ANOVA with degradation time as fixed factor and fragment size as random factor nested in degradation. The assumption of homoscedasticity was met. Although the data did not meet the assumption of normal distribution of residuals (Shapiro Wilk's test, $\alpha=0.05$ ), we selected this parametric analysis because the distribution of residuals was nearly normal in the histograms and the ANOVA is robust to small deviations from normality (Schmider et al. 2010).

All statistical analyses and graphical productions were carried out using the freeware $\mathrm{R}$ statistical environment ( $\mathrm{R}$ Core Team 2018). 


\section{RESULTS}

Environmental parameters. During the experiment, temperature ranged from 11.7 to $17.8{ }^{\circ} \mathrm{C}$ reflecting seasonal fluctuations typically observed in the Bay of Morlaix. No lengthy periods of low light and high RWM were measured between experimental times, indicating that no strong storms were experienced during the experiment (Table 1).

Reproductive tissues, decomposition of biomass, and tissue content. Large remaining fragments seemed visually less affected than small fragments by the degradation process. At weeks 20 and 24 (corresponding to September and October), a total of 3 and 2 large fragments from the new blade cages, respectively, presented reproductive tissues (sori) on their surface. Conversely, no reproductive tissues were observed on the old blade fragments.

The decomposition model showed a good fit on the remaining biomass data for new $\left(R_{\text {raw }}^{2}=0.773\right.$; F-test, $\left.\quad F_{1,7}=23.89, \quad P<0.01\right)$ and old blades $\left(R_{\text {raw }}{ }^{2}=0.633 ; F\right.$-test, $\left.F_{1,5}=8.63, P<0.05\right)$, respectively. The decomposition rate estimated using nonlinear regression was three times higher for old blades $\left(k=0.0366 \cdot \mathrm{d}^{-1}\right)$ compared with new blades $\left(k=0.0107 \cdot \mathrm{d}^{-1}\right)$, corresponding to a fragment degradation half-life $\left(T_{1 / 2}\right)$ of 18.9 and 65.0 days, respectively (Fig. 2b).

The biomass of new Laminaria hyperborea blades decreased with degradation time (Kruskal-Wallis test, $\left.\mathrm{H}_{7}=34.2, \quad P<0.001\right)$. Biomass did not decrease between the set-up and week 2 and even a slight increase was detectable. Biomass loss was detectable after 2 weeks and showed negative exponential dynamics with a rapid loss during the first 11 weeks that slowed down after 15 weeks (Fig. 2a). After 24 weeks (5.5 months), $16.5 \%$ of the initial mass of new blades remained.

The tissue composition of new blades was significantly affected by degradation time (Fig. 2, c and d). Phlorotannin concentration in degrading Laminaria hyperborea fragments increased significantly with time (ANOVA, $F_{7,32}=30.492, P<0.001$ ). The concentration was twice as high after 11 weeks of

TABLE 1. Environmental parameters for each sampling time. Data provided are those measured the week before retrieval. Relative water motion data for week 20 are missing due to sensor failure.

\begin{tabular}{|c|c|c|c|c|c|c|c|}
\hline \multirow[b]{2}{*}{ Time (weeks) } & \multicolumn{3}{|c|}{ Temperature $\left({ }^{\circ} \mathrm{C}\right)$} & \multirow{2}{*}{$\begin{array}{l}\text { Light (lux) } \\
\text { Mean }\end{array}$} & \multicolumn{3}{|c|}{$\begin{array}{l}\text { Relative Water } \\
\text { Motion }\left(\mathrm{m} \cdot \mathrm{s}^{-2}\right)\end{array}$} \\
\hline & Mean & Min & $\operatorname{Max}$ & & Mean & Min & $\operatorname{Max}$ \\
\hline 0 & 12.7 & 12.2 & 13.3 & 2284 & 0.38 & 0.00 & 1.98 \\
\hline 2 & 12.3 & 11.7 & 13.7 & 650 & 0.30 & 0.00 & 2.63 \\
\hline 4 & 13.4 & 12.6 & 14.5 & 1154 & 0.13 & 0.00 & 1.08 \\
\hline 6 & 14.5 & 13.5 & 16.5 & 2260 & 0.25 & 0.00 & 2.02 \\
\hline 11 & 15.9 & 15.2 & 17.1 & 956 & 0.33 & 0.00 & 3.08 \\
\hline 15 & 16.5 & 15.9 & 17.1 & 272 & 0.22 & 0.00 & 2.27 \\
\hline 20 & 17.2 & 16.4 & 17.8 & 199 & - & - & - \\
\hline 24 & 16.1 & 15.9 & 16.4 & 515 & 0.15 & 0.00 & 1.86 \\
\hline
\end{tabular}

degradation compared with any time point from the first 6 weeks. This increase was significant (Tukey's HSD test, $P<0.05$ ) except between weeks 4 and 15 (Tukey's HSD test, $P=0.116$; Fig. 2c). Although data showed a high variability between sampling times, the content in $\mathrm{C}: \mathrm{N}$ (mass ratio) was significantly affected by degradation time (ANOVA, $\left.F_{7,32}=6.138, \quad P<0.001\right)$. The ratio increased slightly from 12.2 after 2 weeks to a maximum of 19.4 after 15 weeks of degradation. The post-hoc Tukey's HSD test showed only some differences between times within the first 6 weeks and after 11 weeks. No significant differences in $\mathrm{C}: \mathrm{N}$ ratio were observed among sampling times after 11 weeks (Fig. 2d). The small increase in $\mathrm{C}: \mathrm{N}$ at week 11 was due to both a decrease in $\mathrm{N}$ content from $2.2 \%$ at week 2 to $1.5 \%$ at week 11 and an increase in $\mathrm{C}$ content from $25.4 \%$ at week 4 to $27.2 \%$ at week 11 (Table 2).

Detritus metabolism. The new-blade litterfall cage respiration rate was significantly influenced by degradation time (Kruskal-Wallis test, $\mathrm{H}_{7}=19.739$, $P<0.01$; Fig. 2e). Respiration decreased 3-fold after 2 weeks of degradation; thereafter, the rate did not vary from 2 to 6 weeks. A gradual increase was measured starting from 11 weeks with a maximum rate after 20 and 24 weeks of degradation (Fig. 2e).

The photosynthetic capacity $\left(F_{\mathrm{v}} / F_{\mathrm{m}}\right)$ of degrading algae varied significantly across degradation time (ANOVA, $F_{7,60}=6.858, P<0.001$ ) and according to fragment size (ANOVA, $F_{7,60}=11.821, P<0.001$; Fig 2f; Table 3). Under optimal conditions, $F_{\mathrm{v}} / F_{\mathrm{m}}$ values range from 0.7 to 0.8 for brown algae (Bischof et al. 1999), and lower values suggest a stress response (Pearson et al. 2009). In large fragments, $\mathrm{F}_{\mathrm{v}} / \mathrm{F}_{\mathrm{m}}$ remained stable (Tukey's HSD test, $\mathrm{p}>0.05$ ) and high (mean ranging from 0.70 to 0.76 ) over the entire 5.5 months study, reflecting an effective maintaining of photosynthetic capacity. By contrast, the $F_{\mathrm{v}} / F_{\mathrm{m}}$ of small fragments was affected over time. Especially after 15 weeks, $F_{\mathrm{v}} / F_{\mathrm{m}}$ values decreased and were highly variable (mean $\pm \mathrm{SD} ; 0.43 \pm 0.24$, $0.32 \pm 0.15,0.59 \pm 0.16$ after 15, 20, 24 weeks, respectively; Fig. 2f).

Variations of bacterial counts during the degradation of Laminaria hyperborea. Bacterial counts on Zobell agar, alginate-Phytagel, and mannitol-Phytagel plates at $20^{\circ} \mathrm{C}$ increased by $1-2$ orders of magnitude in the first two weeks of the experiment (Fig. 3, a, c, and d), and remained stable until the end of the experiment. This variation was found to be statistically significant for counts on alginate-Phytagel (Kruskal-Wallis test, $\mathrm{H}_{5}=11.697, P=0.039$ ) and mannitol-Phytagel (Kruskal-Wallis test, $\mathrm{H}_{5}=11.655$, $P=0.040)$ plates. Notably, some of the colder tolerance taxa might have been inhibited during plate incubation at $20^{\circ} \mathrm{C}$, which is higher than the mean field temperature over the course of the experiment (ca. $15^{\circ} \mathrm{C}$ ). Therefore, our data might provide a lower estimate of the total cultivable bacterial 

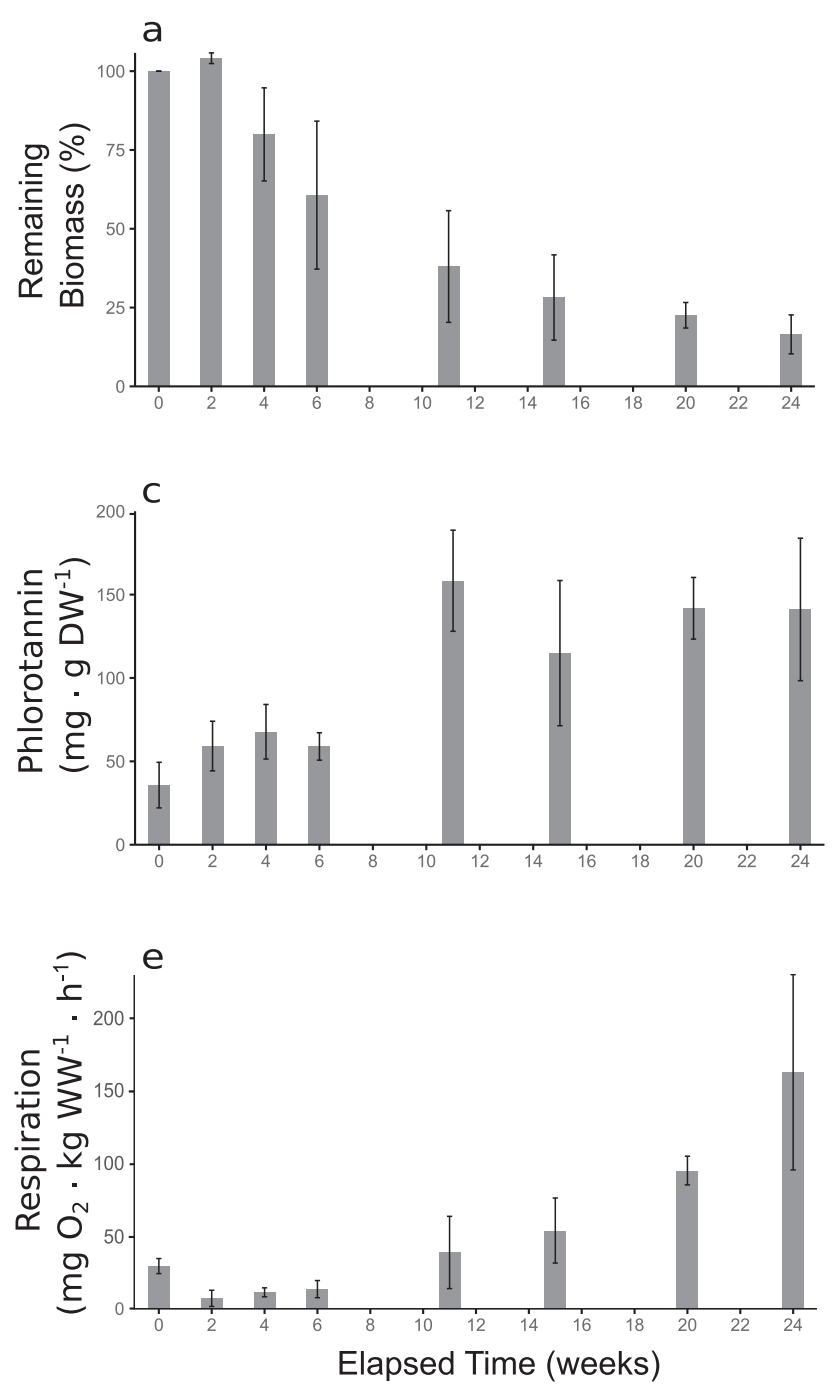
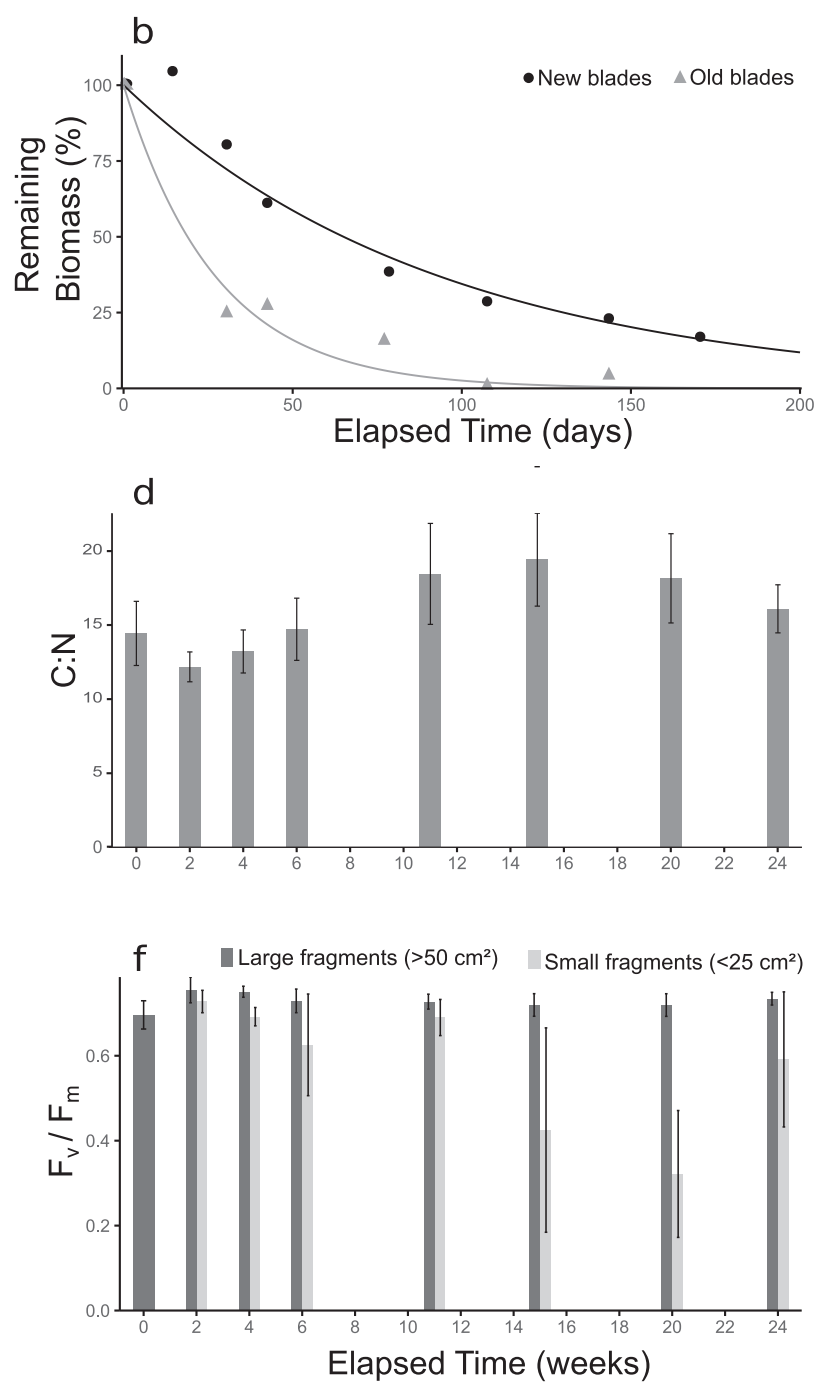

FIG. 2. Parameters of degradation dynamics showing the change in (a) remaining biomass, (b) biomass decomposition models for new blades (black circles) and old blades (gray triangles) cages, (c) phlorotannin content, (d) C:N composition, (e) holobiont respiration rate and (f) $\mathrm{F}_{\mathrm{v}} / \mathrm{F}_{\mathrm{m}}$ values for large (dark gray) and small (light gray) fragments. Bars give means with standard deviations $(\mathrm{n}=5$, except for respiration $\mathrm{n}=3)$. Measures were taken at seven sampling times $(0,2,4,6,11,15,20,24$ weeks). All measures are for new blades, except in panel b.

TABle 2. Tissue content in $\mathrm{C}(\%), \mathrm{N}(\%)$ and $\mathrm{C}: \mathrm{N}$ for each sampling time. Data were expressed as a mass ratio.

\begin{tabular}{|c|c|c|c|c|c|c|}
\hline \multirow[b]{2}{*}{ Time (weeks) } & \multicolumn{2}{|c|}{ C (\%) } & \multicolumn{2}{|c|}{$\mathbf{N}(\%)$} & \multicolumn{2}{|c|}{ C:N } \\
\hline & Mean & SD & Mean & SD & Mean & SD \\
\hline 0 & 28.70 & 1.91 & 2.02 & 0.27 & 14.44 & 2.17 \\
\hline 2 & 26.42 & 0.75 & 2.18 & 0.15 & 12.18 & 1.01 \\
\hline 4 & 25.38 & 1.00 & 1.96 & 0.15 & 13.22 & 1.45 \\
\hline 6 & 25.94 & 0.96 & 1.78 & 0.20 & 14.72 & 2.10 \\
\hline 11 & 27.24 & 2.46 & 1.48 & 0.25 & 18.46 & 3.41 \\
\hline 15 & 27.56 & 1.11 & 1.46 & 0.23 & 19.42 & 3.14 \\
\hline 20 & 29.88 & 1.61 & 1.66 & 0.22 & 18.16 & 3.01 \\
\hline 24 & 26.48 & 0.88 & 1.66 & 0.18 & 16.10 & 1.62 \\
\hline
\end{tabular}

counts. Furthermore, the proportion of iodine-resistant bacteria decreased with time (Kruskal-Wallis test, $\left.\mathrm{H}_{4}=10.5, \quad P=0.033\right)$, from $75 \%$ at the
TABle 3. ANOVA of the effect of time and fragment size on $F_{\mathrm{v}} / F_{\mathrm{m}}$ response. Time was a fixed factor and fragment size was a random factor nested in Time.

\begin{tabular}{lrcrc}
\hline \hline & df & MS & $F$ & $P$ \\
\hline Time & 7 & 0.05839 & 6.858 & $<0.001$ \\
Time:Size & 7 & 0.10064 & 11.821 & $<0.001$ \\
Residuals & 60 & 0.00851 & & \\
\hline
\end{tabular}

beginning of the experiment to $5 \%$ after 24 weeks (Fig. 3b).

\section{DISCUSSION}

Characterizing the kinetics of kelp fragment degradation is essential to understand the quantity 

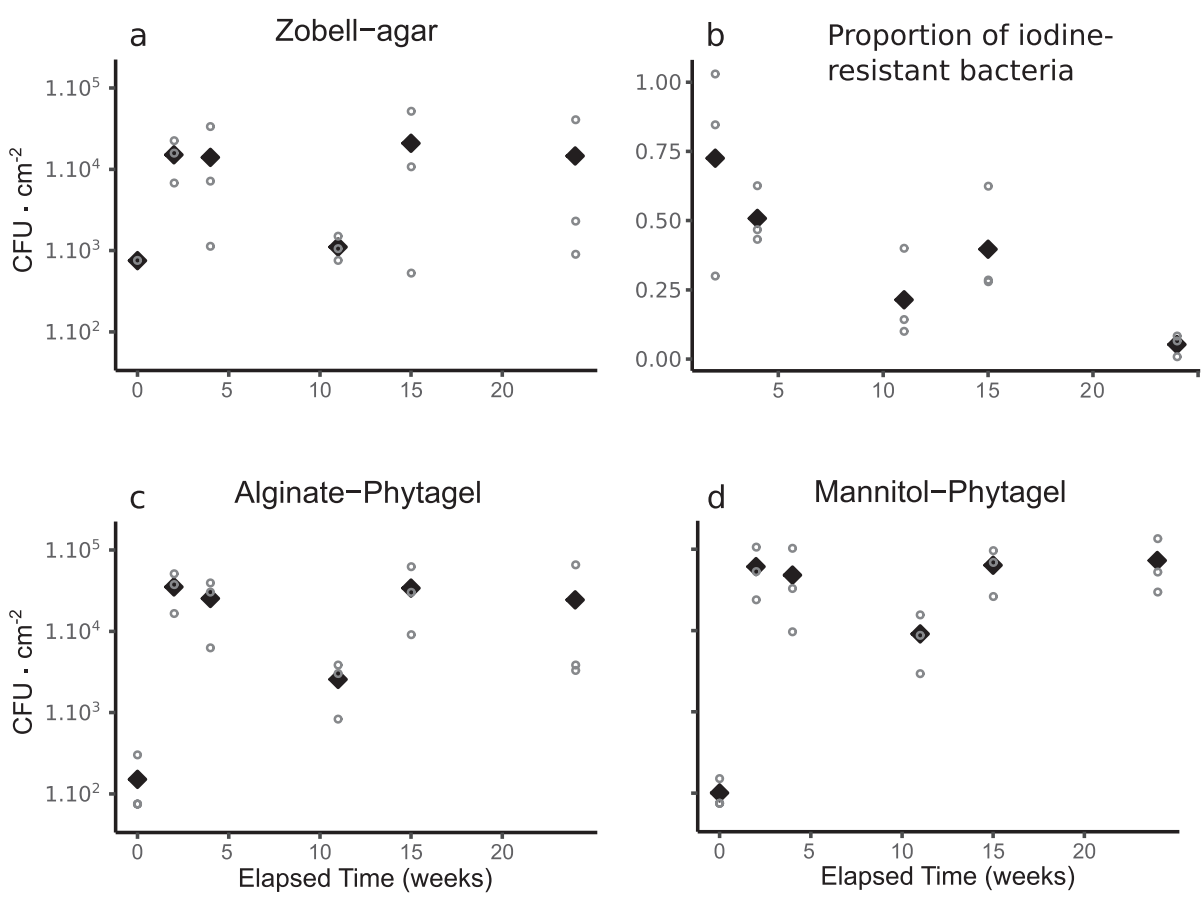

Fig. 3. Cultivable bacterial counts (in number of colony-forming units per unit area of algal tissue: $\mathrm{cfu}^{-\mathrm{cm}^{-2}}$ ) on different growth media: (a) Zobell-agar, (b) KI-supplemented Zobell-agar, (c) alginate-Phytagel, (d) mannitol-Phytagel. Proportion of iodine-resistant bacteria was estimated as the ratio of counts obtained on KI-supplemented Zobell agar relative to the counts obtained on Zobell agar. Open gray circles represent the raw data points from each cage replicate and the black diamonds represent the mean values.

and the residence time of organic matter exported by kelps forests to adjacent habitats. During our experiment, the degradation of kelp biomass followed a classic pattern of organic matter decomposition according to a simple negative exponential model (Enríquez et al. 1993, Nielsen et al. 2004), with high heterogeneity between new and old Laminaria hyperborea blades. Degradation of old blades was three times faster than new blades. This shows that fragments may have different residence times in coastal ecosystems, depending on the export process (detachment of old blades, erosion, or dislodgment during storms). The degradation of kelp organic matter thus follows two different types of patterns. The seasonal export of old blades due to the natural kelp life cycle results in a pulse of organic matter during spring and summer (Pessarrodona et al. 2018), and this tissue degrades relatively quickly. By contrast, material dislodged during periods of high water motion can consist of mixed stipes, new and old blades (Pedersen et al. 2020) with different degradation rates. In benthic systems, the influence of these accumulations or drifting fragments as a transient habitat and resource for adjacent ecosystems can be significant for several months.

The Laminaria hyperborea degradation rate appeared low compared with other macroalgae that dominate coastal ecosystems. The measured degradation rate for young $L$. hyperborea blades is $10-20$ times lower than fast-growing ephemeral algal species such as Ulva sp. $\left(k=0.34-0.51 \cdot \mathrm{d}^{-1}\right)$ or Gracilaria sp. $\left(k=0.5 \cdot \mathrm{d}^{-1}\right.$; Conover et al. 2016), more than 5 times lower than intertidal canopyforming species such as Fucus vesiculosus $(k=0.09$. $\mathrm{d}^{-1}$; Conover et al. 2016), about 3 times lower than other kelp species such as Macrocystis integrifolia for young blades $\left(k=0.032 \cdot \mathrm{d}^{-1}\right.$; Albright et al. 1980) and similar to seagrass species $\left(k=0.01 \cdot \mathrm{d}^{-1}\right.$; Harrison 1989, Hemminga and Nieuwenhuize 1991) and mangrove leaves $\left(k=0.011 \cdot \mathrm{d}^{-1}\right.$; GladstoneGallagher et al. 2014).

In addition, degradation dynamics may be strongly affected by seasonal patterns and environmental conditions including fluctuations in local hydrodynamics and temperature. For example, physical mechanisms certainly fragment detritus more than what we observed within the cages. Furthermore, our study covered the spring-summer period that corresponds to late spring storms. Lower winter temperatures likely slow down the degradation process, but this might be counterbalanced by higher water motion that increases fragmentation. For these reasons, winter and autumn degradation kinetics are not readily predictable. To understand the seasonal degradation variability, an additional study has been conducted during the autumn-winter period, following the same experimental design. Due to storm damage and fishermen anchoring on the experimental system, the obtained data were not exploitable. Further research is also needed to test the effect of 
recipient habitat on degradation dynamics (e.g., depth, wave-exposure).

The photosynthetic capacity of algal tissues was maintained for 5.5 months for large fragments and for 3.5 months for small fragments. These results have wide implications for coastal ecosystem functioning because exported detritus may still perform primary production and renew their tissues, potentially explaining their partial recalcitrance to degradation. In highly hydrodynamic systems such as the English Channel, this recalcitrance may increase the area of influence of kelp forests and magnify their impact on coastal and deep-sea ecosystems. Furthermore, reproductive tissues were observed on degrading fragments during this six-month experiment. They were detected on new-blade fragments in September-October, similar to the beginning of the formation of reproductive tissues in natural population (Kain and Jones 1975). The persistence of reproductive tissues in drift kelp may increase the dispersal capacity of Laminaria hyperborea, partly compensating for the naturally short dispersal range of spores (5-200 m; Fredriksen et al. 1995). This maintenance of reproductive structures has been reported in different floating drifts of Phaeophyceae such as the kelp species Macrocystis spp. (Macaya et al. 2005, Hernández-Carmona et al. 2006) and Durvillaea antarctica (Tala et al. 2013, 2019) and the fucoids species Hormosira banksii (McKenzie and Bellgrove 2008) and Sargassum polycertium (Engelen et al. 2001), suggesting that export of detached reproductive blades is an important mechanism for dispersal. To our knowledge, this is the first time that reproductive tissues have been reported in Laminaria degrading fragments.

Respiration showed a rapid decline at the beginning of the experiment. This early change can be attributed to the capacity of kelps to modulate their metabolism depending on environmental conditions (Kregting et al. 2016). Respiration increased after 11 weeks, likely reflecting a gradual increase in the metabolism of the holobiont complex formed by the degrading kelp and its associated microorganisms. Indeed, we evidenced a rapid colonization of degrading kelp by heterotrophic bacteria (Fig. 3), reaching an apparent maximum abundance as early as 2 weeks after fragmentation. While the apparent abundance of heterotrophic bacteria did not increase after 2 weeks, the rise of respiration rate suggests an increase in overall bacterial activity. This increase in respiration process and bacterial activity could be partly related to an increase in temperature from $12^{\circ} \mathrm{C}$ at the beginning, to $16.5^{\circ} \mathrm{C}$ at week 20.

Kelps possess a unique defense metabolism, including the production of toxic iodine compounds and phlorotannins (Potin et al. 2002). Previous studies suggested that kelps quickly initiate defense responses to minimize grazing pressure and stress soon after dislodgement (Norderhaug et al.
2006). Iodine is highly concentrated in the peripheral cell layers, creating specific niches for associated bacteria during iodovolatilization (Küpper et al. 2008, Verhaeghe et al. 2008). In the present study, the proportion of iodine-tolerant bacteria decreased over time. As Laminaria hyperborea tissue was degrading, iodine from the alga may have been released in the environment, making the associated specific niches disappear and allowing tissue colonization by non-tolerant bacteria. Interestingly, the detected concentration of phlorotannins in degrading tissues stayed stable during the first 6 weeks and only doubled after 11 weeks. Rather than a rapid induction of defense mechanisms, this apparent increase in phlorotannins may reflect the early degradation stage of kelp tissue after 11 weeks. The degradation of cell walls by colonizing bacteria may make phlorotannins more accessible and increase the extraction efficiency during phlorotannin concentration assays.

Tissue content showed a slight increase in C:N over time (maximum 59\% increase) related to a small decrease in $\mathrm{N}$ and a small increase in $\mathrm{C}$ content. Previous studies have shown a clear decrease in the $\mathrm{C}: \mathrm{N}$ ratio related to the degradation of kelps (e.g., 92\% decrease in $44 \mathrm{~d}$ ), reflecting an enrichment in nitrogen which is linked with bacterial degradation (Norderhaug et al. 2006). Our results followed the same pattern as observed by Dethier et al. (2014). The relatively stable $\mathrm{C}$ and $\mathrm{N}$ content could be due to low degradation rates of kelp tissue. Sosik and Simenstad (2013) suggested a complex relationship between $\mathrm{C}: \mathrm{N}$ ratio and microbes, with a preferential consumption of $\mathrm{N}$ by the microbiota and a physical leaching of $\mathrm{C}$ during degradation.

Our study allows a better understanding of in situ Laminaria hyperborea degradation dynamics over the spring/summer period. We highlighted the substantial difference in decomposition kinetics between new and old blades; this has an implication on the residence time of kelp detritus in coastal environments. We showed that new blades have a high capacity to resist degradation, maintaining photosynthesis function for 5.5 months depending on the degree of fragmentation. Confirming this pattern of degradation dynamics requires testing different environmental conditions (hydrodynamism, depth) and seasons in future studies. Furthermore, additional researches are needed to confirm our preliminary results on the maintaining of reproductive function during degradation, which may have substantial implications for dispersal. Under natural conditions, accumulations of marine litterfall vary over time and fragments can drift between different habitats after being exported. These changes in environmental conditions during the degradation process complicate the understanding of the impact of kelp fragments on coastal ecosystems. Due to their large quantity, detritus exported from kelp forests can fuel receiving ecosystems with a pulse of organic 
matter and influence their structure and functioning. Kelp detritus can attract mobile amphipods in high densities (Ramírez-Llodra et al. 2016) and represent an important contribution to benthic food webs (Renaud et al. 2015).

We thank the marine operation staff of Roscoff Biological Station (Service Mer E Observation SBR), especially L. Levêque, Y. Fontana, W. Thomas, M. Camusat, N. Guidal and F. Le Ven for their help with scuba diving fieldwork and experimental set-up. We also thank the Corsaire-Metabomer platform of Roscoff Biological Station (FR2424) for C:N sample analyses. Finally, we are grateful to the three anonymous reviewers whose suggestions greatly improved the manuscript. This work benefited from the support of the Brittany Regional Council and the French Government through the National Research Agency with regard to the investment expenditure program IDEALG (reference: ANR10-BTBR-04).

\section{AUTHOR CONTRIBUTIONS}

$\mathrm{FdB}$, PD, and DD conceived the ideas and designed the study. FdB, OB, FT, AG, and LD processed samples. FdB and DD analyzed the data. FdB, DD, OB, and SL collected the data. FdB and DD wrote the first draft, and PD, FT, AG, and LD extensively contributed to the corrections.

Abdullah, M. I., Fredriksen, S. \& Christie, H. 2017. The impact of the kelp (Laminaria hyperborea) forest on the organic matter content in sediment of the west coast of Norway. Mar. Biol. Res. 13:151-160.

Adair, E. C., Hobbie, S. E. \& Hobbie, R. K. 2010. Single-pool exponential decomposition models: potential pitfalls in their use in ecological studies. Ecology 91:1225-36.

Albright, L. J., Chocair, J., Masuda, K. \& Valdés, M. 1980. In situ degradation of the kelps Macrocystis integrifolia and Nereocystis luetkeana in British Columbia coastal waters. Nat. Can. 107:3-10

Amsler, C. D. \& Fairhead, V. A. 2006. Defensive and sensory chemical ecology of brown algae. Adv. Bot. Res. 43:1-91.

Bennett, S., Wernberg, T., de Bettignies, T., Kendrick, G. A., Anderson, R. J., Bolton, J. J., Rodgers, K. L. et al. 2015. Canopy interactions and physical stress gradients in subtidal communities. Ecol. Lett. 18:677-86.

Bischof, K., Hanelt, D. \& Wiencke, C. 1999. Acclimation of maximal quantum yield of photosynthesis in the brown alga Alaria esculenta under high light and UV radiation. Plant Biol. $1: 435-44$.

Bustamante, R. H., Branch, G. M. \& Eekhout, S. 1995. Maintenance of an exceptional intertidal grazer biomass in South Africa: subsidy by subtidal kelps. Ecology 76:2314-29.

Cardona, L., Revelles, M., Sales, M., Aguilar, A. \& Borrell, A. 2007. Meadows of the seagrass Posidonia oceanica are a significant source of organic matter for adjoining ecosystems. Mar. Ecol. Prog. Ser. 335:123-31.

Christie, H., Jørgensen, N. M., Norderhaug, K. M. \& Waage-Nielsen, E. 2003. Species distribution and habitat exploitation of fauna associated with kelp (Laminaria hyperborea) along the Norwegian coast. J. Mar. Biol. Assoc. UK 83:687-99.

Conover, J., Green, L. A. \& Thornber, C. S. 2016. Biomass decay rates and tissue nutrient loss in bloom and nonbloom-forming macroalgal species. Estuar. Coast. Shelf Sci. 178:58-64.

de Bettignies, T., Wernberg, T., Lavery, P. S., Vanderklift, M. A. \& Mohring, M. B. 2013. Contrasting mechanisms of dislodgement and erosion contribute to production of kelp detritus. Limnol. Oceanogr. 58:1680-8.
Dethier, M. N., Brown, A. S., Burgess, S., Eisenlord, M. E., Galloway, A. W. E., Kimber, J., Lowe, A. T., O'Neil, C. M., Raymond, W. W., Sosik, E. A. \& Duggins, D. O. 2014. Degrading detritus: changes in food quality of aging kelp tissue varies with species. J. Exp. Mar. Biol. Ecol. 460:72-9.

Edwards, M. S. \& Kim, K. Y. 2010. Diurnal variation in relative photosynthetic performance in giant kelp Macrocystis pyrifera (Phaeophyceae, Laminariales) at different depths as estimated using PAM fluorometry. Aquat. Bot. 92:119-28.

Engelen, A. H., Olsen, J. L., Breeman, A. M. \& Stam, W. T. 2001. Genetic differentiation in Sargassum polycertium (Fucales: Phaeophyceae) around the island of Curacao (Netherlands Antilles). Mar. Biol. 139:267-77.

Enríquez, S., Duarte, C. M. \& Sand-Jensen, K. A. J. 1993. Patterns in decomposition rates among photosynthetic organisms: the importance of detritus C: N: P content. Oecologia 94:457-71.

Evans, S. N. \& Abdo, D. A. 2010. A cost-effective technique for measuring relative water movement for studies of benthic organisms. Mar. Freshw. Res. 61:1327-35.

Filbee-Dexter, K. \& Scheibling, R. E. 2014. Detrital kelp subsidy supports high reproductive condition of deep-living sea urchins in a sedimentary basin. Aquat. Biol. 23:1-86.

Filbee-Dexter, K., Wernberg, T., Norderhaug, K. M., Ramirez-Llodra, E. \& Pedersen, M. F. 2018. Movement of pulsed resource subsidies from kelp forests to deep fjords. Oecologia 187:291-304.

Fredriksen, S., Sjøtun, K., Lein, T. E. \& Rueness, J. 1995. Spore dispersal in Laminaria hyperborea (Laminariales, Phaeophyceae). Sarsia 80:47-53.

Gevaert, F., Creach, A., Davoult, D., Holl, A. C., Seuront, L. \& Lemoine, Y. 2002. Photo-inhibition and seasonal photosynthetic performance of the seaweed Laminaria saccharina during a simulated tidal cycle: chlorophyll fluorescence measurements and pigment analysis. Plant Cell Environ. 25:859-72.

Gladstone-Gallagher, R., Lundquist, C. \& Pilditch, C. 2014. Mangrove (Avicennia marina subsp. australasica) litter production and decomposition in a temperate estuary. New Zeal. J. Mar. Fresh. 48:24-37.

Gorman, D., Bajjouk, T., Populus, J., Vasquez, M. \& Ehrhold, A. 2013. Modeling kelp forest distribution and biomass along temperate rocky coastlines. Mar. Biol. 160:309-25.

Harrison, P. G. 1989. Detrital processing in seagrass systems: a review of factors affecting decay rates, remineralization and detritivory. Aquat. Bot. 35:263-88.

Hemminga, M. A. \& Nieuwenhuize, J. 1991. Transport, deposition and in situ decay of seagrasses in a tropical mudflat area (Banc D'Arguin, Mauritania). Neth. J. Sea Res. 27:183-90.

Hendricks, J. J. \& Boring, L. R. 1992. Litter quality of native herbaceous legumes in a burned pine forest of the Georgia Piedmont. Can. J. For. Res. 22:2007-10.

Hereward, H. F. R., Foggo, A., Hinckley, S. L., Greenwood, J. \& Smale, D. A. 2018. Seasonal variability in the population structure of a habitat-forming kelp and a conspicuous gastropod grazer: Do blue-rayed limpets (Patella pellucida) exert top-down pressure on Laminaria digitata populations? J. Exp. Mar. Biol. Ecol. 506:171-81.

Hernández-Carmona, G., Hughes, B. \& Graham, M. H. 2006. Reproductive longevity of drifting kelp Macrocystis pyrifera (Phaeophyceae) in Monterey Bay. USA. J. Phycol. 42:1199-207.

Hyndes, G. A., Lavery, P. S. \& Doropoulos, C. 2012. Dual processes for cross-boundary subsidies: incorporation of nutrients from reef-derived kelp into a seagrass ecosystem. Mar. Ecol. Prog. Ser. 445:97-107.

Iwamoto, K. \& Shiraiwa, Y. 2005. Salt-regulated mannitol metabolism in algae. Mar. Biotechnol. 7:407-15.

Kain, J. \& Jones, N. 1975. The biology of Laminaria hyperborea VII. Reproduction of the sporophyte. J. Mar. Biolog. Assoc. UK 55:567-82.

Kloareg, B. \& Quatrano, R. S. 1988. Structure of the cell walls of marine algae and ecophysiological functions of the matrix polysaccharides. Ocean. Mar. Biol. Annu. Rev. 26:259-315. 
Koivikko, R., Loponen, J., Pihlaja, K. \& Jormalainen, V. 2007. High-performance liquid chromatographic analysis of phlorotannins from the brown algae Fucus vesiculosus. Phytochem. Anal. 18:326-32.

Kregting, L., Blight, A. J., Elsäßer, B. \& Savidge, G. 2016. The influence of water motion on the growth rate of the kelp Laminaria digitata. J. Exp. Mar. Biol. Ecol. 478:86-95.

Krishna, M. P. \& Mohan, M. 2017. Litter decomposition in forest ecosystems: a review. Energy Ecol. Environ. 2:236-49.

Krumhansl, K. \& Scheibling, R. 2012a. Production and fate of kelp detritus. Mar. Ecol. Prog. Ser. 467:281-302.

Krumhansl, K. \& Scheibling, R. 2012b. Detrital subsidy from subtidal kelp beds is altered by the invasive green alga Codium fragile ssp. fragile. Mar. Ecol. Prog. Ser. 456:73-85.

Küpper, F. C., Carpenter, L. J., McFiggans, G. B., Palmer, C. J., Waite, T. J., Boneberg, E. M., Woitsch, S. et al. 2008. Iodide accumulation provides kelp with an inorganic antioxidant impacting atmospheric chemistry. Proc. Natl. Acad. Sci. USA 105:6954-8.

Leclerc, J. C., Riera, P., Laurans, M., Leroux, C., Lévêque, L. \& Davoult, D. 2015. Community, trophic structure and functioning in two contrasting Laminaria hyperborea forests. Estuar. Coast. Shelf Sci. 152:11-22.

Li, Y., Fu, X., Duan, D., Liu, X., Xu, J. \& Gao, X. 2017. Extraction and identification of phlorotannins from the brown alga, Sargassum fusiforme (Harvey) Setchell. Mar. Drugs 15:49.

Ling, S. D., Scheibling, R. E., Rassweiler, A., Johnson, C. R., Shears, N., Connell, S. D., Salomon, A. K. et al. 2014. Global regime shift dynamics of catastrophic sea urchin overgrazing. Philos. Trans. R. Soc. B Biol. Sci. 370:20130269.

Lüning, K. 1979. Growth strategies of three Laminaria species (Phaeophyceae) inhabiting different depth zones in the sublittoral region of Helgoland (North Sea). Mar. Ecol. Prog. Ser. 1:195-207.

Macaya, E. C., Boltana, S., Hinojosa, I. A., Macchiavello, J. E., Valdivia, N. A., Vasquez, N. R., Buschmann, A. H., Vasquez, J. A., Alonso Vega, J. M. \& Thiel, M. 2005. Presence of sporophylls in floating kelp rafts of Macrocystis spp. (Phaeophyceae) along the Chilean Pacific. Coast. J. Phycol. 41:913-22.

Mann, K. H. 1973. Seaweeds: their productivity and strategy for growth. Science 182:975-81.

Matala, J., Kellomäki, S. \& Nuutinen, T. 2008. Litterfall in relation to volume growth of trees: analysis based on literature. Scand. J. For. Res. 23:194-202.

McKenzie, P. F. \& Bellgrove, A. 2008. Dispersal of Hormosira banksii (Phaeophyceae) via detached fragments: reproductive viability and longevity. J. Phycol. 44:1108-15.

Miller, H. G. 1984. Dynamics of nutrient cycling in plantation ecosystems. In Bowen, G. D. \& Nambiar, E. K. S. [Eds.] Nutrition of Plantation Forests. Academic Press, London, pp. 53-78.

Nielsen, S. L., Banta, G. T. \& Pedersen, M. F. 2004. Decomposition of marine primary producers: consequences for nutrient recycling and retention in coastal ecosystems. In Nielsen, S. L., Banta, G. T. \& Pedersen, M. F. [Eds.] Estuarine Nutrient Cycling: The Influence of Primary Producers. Springer, Dordrecht, pp. 187-216.

Norderhaug, K. M., Fredriksen, S. \& Nygaard, K. 2003. Trophic importance of Laminaria hyperborea to kelp forest consumers and the importance of bacterial degradation to food quality. Mar. Ecol. Prog. Ser. 255:135-44.

Norderhaug, K. M., Nygaard, K. \& Fredriksen, S. 2006. Importance of phlorotannin content and C : $\mathrm{N}$ ratio of Laminaria hyperborea in determining its palatability as food for consumers. Mar. Biol. Res. 2:367-71.

Norkko, J., Bonsdorf, E. \& Norkko, A. 2000. Drifting algal mats as an alternative habitat for benthic invertebrates: species specific responses. J. Exp. Mar. Biol. Ecol. 248:79-104.

Okey, T. A. 2003. Macrobenthic colonist guilds and renegades in Monterey Canyon (USA) drift algae: partitioning multidimensions. Ecol. Monogr. 73:415-40.

Olson, J. S. 1963. Energy storage and the balance of producers and decomposers in ecological systems. Ecology 44:322-31.
Ouisse, V., Migné, A. \& Davoult, D. 2014. Comparative study of methodologies to measure in situ the intertidal benthic community metabolism during immersion. Estuar. Coast. Shelf Sci. 136:19-25.

Pandey, R. R., Sharma, G., Tripathi, S. K. \& Singh, A. K. 2007. Litterfall, litter decomposition and nutrient dynamics in a subtropical natural oak forest and managed plantation in northeastern India. For. Ecol. Manag. 240:96-104.

Pearson, G. A., Lago-Leston, A. \& Mota, C. 2009. Frayed at the edges: selective pressure and adaptive response to abiotic stressors are mismatched in low diversity edge populations. $J$. Ecol. 97:450-62.

Pedersen, M. F., Filbee-Dexter, K., Norderhaug, K. M., Fredriksen, S., Frisk, N. L. \& Wernberg, T. 2020. Detrital carbon production and export in high latitude kelp forests. Oecologia 192:227-39.

Pergent, G., Romero, J., Pergent-Martini, C., Mateo, M. A. \& Boudouresque, C. F. 1994. Primary production, stocks and fluxes in the Mediterranean seagrass Posidonia oceanica. Mar. Ecol. Prog. Ser. 106:139-46.

Pessarrodona, A., Moore, P. J., Sayer, M. D. J. \& Smale, D. A. 2018. Carbon assimilation and transfer through kelp forests in the NE Atlantic is diminished under a warmer ocean climate. Glob. Change Biol. 24:4386-98.

Polyakova, O. \& Billor, N. 2007. Impact of deciduous tree species on litterfall quality, decomposition rates and nutrient circulation in pine stands. For. Ecol. Manag. 253:11-18.

Potin, P., Bouarab, K., Salaün, J. P., Pohnert, G. \& Kloareg, B. 2002. Biotic interactions of marine algae. Curr. Opin. Plant Biol. 5:308-17.

$\mathrm{R}$ Core Team. 2018. $R$ : a language and environment for statistical computing, version 3.5.2. R Foundation for Statistical Computing, Vienna.

Ramírez-Llodra, E., Rinde, E., Gundersen, H., Christie, H., Fagerli, C. W., Fredriksen, S., Gitmark, J. K., Norling, K., Walday, M. G. \& Norderhaug, K. M. 2016. A snap shot of the short-term response of crustaceans to macrophyte detritus in the deep Oslofjord. Sci. Rep. 6:23800.

Rees, R. M., Ball, B. C., Campbell, C. D. \& Watson, C. A. 2001. Sustaining soil organic matter. In Rees, R. M., Ball, B. C., Campbell, C. D. \& Watson, C. A. [Eds.] Sustainable Management of Soil Organic Matter. CABI Publishing, New York, USA, pp. 413-426.

Renaud, P. E., Løkken, T. S., Jørgensen, L. L., Berge, J. \& Johnson, B. J. 2015. Macroalgal detritus and food-web subsidies along an Arctic fjord depth-gradient. Front. Mar. Sci. 2:31.

Schiener, P., Black, K. D., Stanley, M. S. \& Green, D. H. 2015. The seasonal variation in the chemical composition of the kelp species Laminaria digitata, Laminaria hyperborea, Saccharina latissima and Alaria esculenta. J. Appl. Phycol. 27:363-73.

Schmider, E., Ziegler, M., Danay, E., Beyer, L. \& Bühner, M. 2010. Is it really robust? Reinvestigating the robustness of ANOVA against violations of the normal distribution assumption. Methodology 6:147-51.

Sivertsen, K. 1997. Geographic and environmental factors affecting the distribution of kelp beds and barren grounds and changes in biota associated with kelp reduction at sites along the Norwegian coast. Can. J. Fish. Aquat. Sci. 54:2872-87.

Sjøtun, K., Fredriksen, S. \& Rueness, J. 1996. Seasonal growth and carbon and nitrogen content in canopy and first-year plants of Laminaria hyperborea (Laminariales, Phaeophyceae). Phycologia 35:1-8.

Sosik, E. \& Simenstad, C. 2013. Isotopic evidence and consequences of the role of microbes in macroalgae detritus-based food webs. Mar. Ecol. Prog. Ser. 494:107-119.

Steneck, R. S., Graham, M. H., Bourque, B. J., Corbett, D., Erlandson, J. M., Estes, J. A. \& Tegner, M. J. 2002. Kelp forest ecosystems: biodiversity, stability, resilience and future. Environ. Conserv. 29:436-59.

Tala, F., Gómez, I., Luna-Jorquera, G. \& Thiel, M. 2013. Morphological, physiological and reproductive conditions of rafting bull kelp (Durvillaea antarctica) in northern-central Chile (30º). Mar. Biol. 160:1339-51.

Tala, F., López, B. A., Velásquez, M., Jeldres, R., Macaya, E. C., Mansilla, A., Ojeda, J. \& Thiel, M. 2019. Long-term 
persistence of the floating bull kelp Durvillaea antarctica from the South-East Pacific: potential contribution to local and transoceanic connectivity. Mar. Environ. Res. 149:67-79.

Teagle, H., Hawkins, S. J., Moore, P. J. \& Smale, D. A. 2017. The role of kelp species as biogenic habitat formers in coastal marine ecosystems. J. Exp. Mar. Biol. Ecol. 492:81-98.

Thomas, F., Cosse, A., Goulitquer, S., Raimund, S., Morin, P., Valero, M., Leblanc, C. \& Potin, P. 2011. Waterborne signaling primes the expression of elicitor-induced genes and buffers the oxidative responses in the brown alga Laminaria digitata. PLoS ONE 6:e21475.

Toth, G. B. \& Pavia, H. 2002. Intraplant habitat and feeding preference of two gastropod herbivores inhabiting the kelp Laminaria hyperborea. J. Mar. Biol. Assoc. UK 82:243-7.

Tzetlin, A. B., Mokievsky, V. O., Melnikov, A. N., Saphonov, M. V., Simdyanov, T. G. \& Ivanov, I. E. 1997. Fauna associated with detached kelp in different types of subtidal habitats of the White Sea. Hydrobiologia 355:91-100.

Van Alstyne, K. L., McCarthy, J. J., Hustead, C. L. \& Kearns, L. J. 1999. Phlorotannin allocation among tissues of northeastern pacific kelps and rockweeds. J. Phycol. 35:483-92. van Wesemael, B. \& Veer, M. A. C. 1992. Soil organic matter accumulation, litter decomposition and humus forms under mediterranean-type forests in southern Tuscany, Italy. J. Soil Sci. 43:133-44.

Verhaeghe, E. F., Fraysse, A., Guerquin-Kern, J. L., Wu, T. D., Devès, G., Mioskowski, C., Leblanc, C., Ortega, R., Ambroise, Y. \& Potin, P. 2008. Microchemical imaging of iodine distribution in the brown alga Laminaria digitata suggests a new mechanism for its accumulation. J. Biol. Inorg. Chem. $13: 257-269$

Vetter, E. W. 1994. Hotspots of benthic production. Nature 372:47.

Vilas, D., Coll, M., Pedersen, T., Corrales, X., Filbee-Dexter, K., Pedersen, M. F., Norderhaug, K. M. et al. 2020. Kelp-carbon uptake by Arctic deep-sea food webs plays a noticeable role in maintaining ecosystem structural and functional traits. $J$. Mar. Syst. 203:103268.

Zhang, Q., Zhang, J., Shen, J., Silva, A., Dennis, D. A. \& Barrow, C. J. 2006. A Simple 96-Well microplate method for estimation of total polyphenol content in seaweeds. J. Appl. Phycol. $18: 445-50$. 